\title{
ADVANCING ELECTRONIC VOTING SYSTEMS IN NIGERIA'S ELECTORAL PROCESS: LEGAL CHALLENGES AND FUTURE DIRECTIONS
}

\author{
Obinne Obiefuna-Oguejiofor*
}

Voting is a uniquely difficult question for computers: the system must verify your eligibility to vote; know whether you have already voted; and allow for audits and recounts. Yet it must always preserve your anonymity and privacy. Currently, there are no practical solutions to this highly complex problem and existing systems are unacceptably flawed. ${ }^{1}$

\begin{abstract}
This article aims to examine the legal and policy challenges associated with adopting an electronic voting (e-voting) system in Nigeria's electoral process. Nigeria, Africa's largest democracy, has for many years been held down by issues of election fraud, thuggery, violence as seen in past manual elections in the country. The article argues that, if properly implemented and financed, $e$-election offers great promise and potential as the panacea for voter fraud in Nigeria's electoral system. First, it examines the theoretical, legal and constitutional basis for e-voting. Second, drawing lessons from other jurisdictions, it analyses practical challenges for the implementation and adoption of an e-voting system in Nigeria. These challenges include the possible compromise of e-voting devices, by viruses or other malicious software; manipulation by people with privileged access to the system, either system developers, system administrators or malicious hackers; denial-of-service attacks (attacks that result in the e-voting facility being disabled or otherwise unavailable for voters to use); lack of adequate supervision mechanisms; and the difficulties of proving electronic attacks in courts of law among other things. Many of these problems are beyond the contemplation of and, therefore, are unaddressed by Nigeria's Electoral Act, making the law currently incapable
\end{abstract}

* LLB Nigeria, LLM Essex B L., Lecturer in Law, Department of Jurisprudence and Legal Theory, University of Nigeria. Email: obinne.oguejiofor@unn.edu.ng.

1 "Digital Democracy Report, "Open Up: Report of the Speaker's Commission on Digital Democracy" (26 January 2015) < http://www.digitaldemocracy. parliament.uk/documents/Open-Up-Digital-Democracy-Report. pdf $>$ accessed 4 June 2018. 
and unsuitable to effectively respond to these problems. The article calls for a reform of the Nigerian Electoral Act to better address peculiar legal and constitutional challenges associated with e-voting systems.

Keywords: E-elections, Hacking, Democracy, Election Piloting

DOI: https://dx.doi.org/10.4314/jsdlp.v9i2.10

\section{INTRODUCTION}

The promise of the e-voting tool for furthering a democratic culture has been heralded globally in recent academic literature. ${ }^{2}$ Globally, e-voting is becoming a well-accepted trend for exercising electoral franchise. E-voting is simply an election system that allows voters to use electronic tools and processes for the casting, transmitting and counting of votes. ${ }^{3}$

Countries such as Estonia, Namibia, Brazil, and Australia have adopted it. ${ }^{4}$ Its advantages include the reduction of workload associated with processing votes, ease of compilation of election results, timely announcing of election results, and eradication of human error. With e-voting, Nigeria can overcome voter fraud, impersonation, multiple voting and constitute a major step in restoring public faith in an electoral system bedevilled with challenges. Ballot stuffing theft, spoilt ballots

2 Emad Abu-Shanab, HebaRefa, Michael Knight. "E-voting Systems: A Tool for EDemocracy" (2010) 2(3) Management Research and Practice 264.

3 Ibid. There are different types of e-voting systems, ranging from computerbased polling stations, paper-based systems, such as punch cards, optical scan systems, mechanical lever machines, and remote e-voting systems like Polyas, Helios, and mobile voting systems such as SMS voting, all of which allow voters to use electronic tools and processes for the casting, transmitting and counting of votes. In this article electronic voting, e-election, internet voting are used interchangeably. But there are differences. E-voting: is physically supervised by representatives of governmental or independent electoral authorities (e.g. use electronic voting machines located at polling stations); this is the most common approach and i-voting: also referred to as remote e-voting is where voting is performed within the voter's sole influence, and is not physically supervised by representatives of governmental authorities (e.g. voting from one's personal computer, mobile phone, television or via the internet). See Denise Demirel, Richard Frankland \& Melanie Volkamer, Readiness of Various E-voting System for Complex Elections (CASED Technical Report, 15 July 2011) 1-3.

4 Ibid. 
could also be a thing of the past with e-voting. Furthermore, e-voting has the tendency to inculcate civic duties in the future leaders of tomorrow as it has played a role in advancing member engagement and supported performance of the most important civic duty. Also, e-voting has been noted to enhance community capacity by bringing segments of the community together that might not have interacted otherwise. ${ }^{5}$ In Canada, researchers cited online voting as a policy change that brought together youth and elders in meaningful dialogue. ${ }^{6}$ E-voting carries important implications for empowerment and selfdetermination. Online voting is equally seen as a way to promote voter access (particularly among citizens living in the hinterland), boost turnout, enhance self-determination and modernize voting processes.

Furthermore, offering e-voting could potentially reduce the waiting time and costs of voting for citizens who would otherwise have to travel to the community to cast a ballot, or who would vote by mail if that option is available. ${ }^{7}$ E-elections enhance electoral participation; youths in Nigeria will be more likely to embrace the e-voting method for its convenience and access. This is a positive step in the spirit of the principle of catching them young. ${ }^{8}$

However, the hacking by Russian officials into the email server of the Democratic Party during the 2016 American presidential election campaign is an example of the potential dangers of e-voting. ${ }^{9}$ In Nigeria, when e-voting was trialled during the 2015 general election, it triggered national outrage and embarrassment when the then president Goodluck

5 Ibid.

6 Liam Mizhain-Gobin, Nicole Goodman, Chelsea Gabel, Karen Bird, "Reforming the Indian Act to Allow for Online Voting" (2017) <http:// policyoptions.irpp.org/magazines/october-2017/reforming-the-indian-act-toallow-for-online-voting/> accessed 20th June 2018.

7 Sylvia Uchenna Agu, Vincent Onyekwelu, Sunday Okeke, Adeline Idike. "Voter Apathy and the Revival of Genuine Political Participation in Nigeria" (2013) 4 Mediterranean Journal of Social Sciences 56.

8 Nnaeto Japheth Olusadum, Ndoh Juliet Anulika, Electronic Voting and Credible Election in Nigeria: A Study of Owerri Senatorial Zone (2018) 9(3) Journal of Management and Strategy 30.

9 Russia equally attempted to meddle in other elections in the UK and Europe. Furthermore Russia-backed hackers allegedly exploited vulnerabilities in the websites of perhaps dozens of U.S. State election agencies, and in at least one case were able to alter votes. John Zorabedin, "We Are Already at Cyber War, and We Are Losing)" (2017) < https://www.veracode.com/blog/securedevelopment/were-already-cyberwar-and-were-losing > accessed 4 June 2018. 
Jonathan, his wife and his mother could not be accredited at the polling booth for half an hour due to the malfunctioning of Independent Electoral Commission (INEC)'s Smart Card Reader (SCR). ${ }^{10}$ The then president had to be accredited manually after four card readers failed to work. ${ }^{11}$ This was an embarrassment to INEC officials and Nigeria as the incidence was beamed over the world by the television cameras.

These incidents highlight some of the problems that must be thoroughly examined before adopting e-voting systems for elections in Nigeria. ${ }^{12}$ If not tackled, these problems may later translate to voter loss of confidence and protracted litigations by contestants after elections. ${ }^{13}$ Western countries face this dilemma too. ${ }^{14}$ The reliability of voting technology, adequacy of the size and numbers of polling stations and the availability of trained staff all require significant resources.

As preparations get underway in Nigeria for the 2019 general elections, stakeholders in the country have been clamouring for the adoption of e-election. ${ }^{15}$ This article, while appreciating and, indeed, supporting the clamour for e-election in Nigeria over the traditional means of voting, seeks to highlight the peculiar vulnerabilities associated with it. These vulnerabilities include the compromise of e-voting devices by viruses or other malicious software and possible malfunctioning of the electronic voting machine. Nigeria should be prepared to face any

10 "Addressing The Card Reader Challenge" This Day Newspapers (Abuja, 24 April 2015) 24.

11 Jola Sotubo, "Jonathan Finally Accredited without Card Reader" Pulse (Lagos, 28 March 2015) < https://www.pulse.ng/news/politics/nigeria-elections2015-jonathan-finally-accredited-without-card-reader-id3609880.html > accessed 23rd June 2018

12 The above assertion does not state the fact that manual elections are rig-free; rather, it buttresses the inconvenient truth that e-election is not fool proof and we should equally be aware of the challenges and gear towards addressing the challenges. See Denise Demirel, Richard Frankland \& Melanie Volkamer, Readiness of Various E-voting System for Complex Elections (CASED Technical Report, 15 July 2011) 1-3.

13 See Obi v INEC Unreported CA/E/EPT/5C/2005. The plaintiff had to do a protracted battle in court for three years before his stolen mandate as governor of Anambra state was restored to him.

14 Graeme Orr, Ritual and Rhythm in Electoral Systems: A Comparative Legal Account (Routledge, 2015) 2.

15 See Nnaeto Japheth Olusadum, Ndoh Juliet Anulika, Electronic Voting and Credible Election in Nigeria: A Study of Owerri Senatorial Zone (2018) 9(3) Journal of Management and Strategy 30. 
challenges that may emerge as it transits from manual to electronic voting. Where the necessary apparatus is established to accommodate e-elections in Nigeria, the technological leap can serve as a bulwark against the incessant occasions of electoral violence. With e-voting, Nigeria could lead the way in demonstrating a method of voting that overcomes major hurdles facing young democracies in Africa, namely, selection instead of election, institutionalized corruption, vote selling and accompanying public mistrust of election results. The eradication of fraudulent election through e-voting is not only a victory for Nigeria and its 196 million citizens, it reaches beyond its borders. As Africa's largest economy, this success will resonate and have profound significance for other African nations.

There is an urgent need to carefully examine and consider the potential legal challenges of adopting an e-voting system in Nigeria. There should be a careful assessment of the legal, policy and technology terrain in the adoption of e-elections in Nigeria to effectively instil confidence in the electorate that their votes will count and that elections will be free and fair. ${ }^{16} \mathrm{E}$-voting adoption is an alternative to the lack of transparency, loss of confidence and trust in the electoral process that has enveloped the manual voting system in Nigeria. Given that e-voting has the potential to increase inclusion of apathetic members of our society, especially the youths by making it easier for them to cast their votes in a more convenient and user-friendly way, a cross-section of citizens has been intensifying the campaign to adopt the system.

This article is organized into five sections. After this introduction, section 2 assesses the historical odyssey of manual elections in Nigeria, highlighting the challenges faced by Nigeria in conducting manual elections. These challenges call for a more transparent and trusted method of voting, setting the stage for the e-election campaigners. Section 3 examines the legal and practical challenges to e-voting, most especially the gaps in Nigeria's extant electoral laws. This section equally discusses legal steps for addressing the gaps and challenges facing an electronic voting system in Nigeria. Section 4 highlights the potential challenges faced by adopting e-voting and argues that no system is free from flaws. E-voting, despite its shortcomings, is a panacea to electoral fraud in Nigeria. Section 5 is the conclusion.

16 Bev Harris, Black Box Voting: Ballot Tampering in the Twenty-First Century (Talien Publishing, 2004) 4. 


\section{THE SEARCH FOR FREE, FAIR AND TRANSPARENT VOTING SYSTEMS IN NIGERIA}

Modern democracies rely on free, fair and credible elections. ${ }^{17}$ The outcomes of elections can impact voters' personal freedoms, taxes, and other aspects of daily life that they take for granted. Free, fair and credible elections are therefore essential pathways to achieving sustainable development in any country. ${ }^{18}$ Given the far-reaching impact that an election can have, people have the duty to cast their vote if they want a say in how their futures play out. The electoral process in democratic societies is significant. Centuries ago, people gave their lives to be allowed to vote. ${ }^{19}$ The sacrifice of citizens to exercise this all-important right underscores the importance of elections. Voting is a formal expression of preference for a candidate for office. ${ }^{20}$ Voting is the heart of democracy; our votes are our voices, and collectively a country's vote is its voice. Whether it is a vote to elect the dean of a faculty or a vote to elect a country's president; all votes are important. ${ }^{21}$ In the early medieval times, participating in elections was the sole preserve of upper-class citizens; slaves and the poor freeborn were disenfranchised from the voting process. In the United States, during the slavery era, voting rights were accorded if you were male, white and a property owner. Nigeria practised its first electoral franchise in 1922 under the Hugh Clifford Constitution. ${ }^{22}$ The franchise given to Nigerians in this Constitution was partial suffrage. The right was limited to adult males resident in Lagos and who earned an annual income of $£ 100$. Nigeria did not achieve the status of universal adult suffrage

17 Anika Gauja, Political Parties and Elections Legislating for Representative Democracy (Routledge, 2010) 63.

18 Georg Sorensen, Democracy and Democratization: Processes and Prospects in a Changing World (3rd edn, Avalon Publishing, 2007) 1.

19 In the mid-nineteenth century, the women suffragist movement was born. This was to allow women to cast their votes at elections, See Sylvia Prankhurst, The Suffragette: The History of the Women's Militant Suffrage Movement (Dover Publications, 2015) 8.

20 Daniel Mcool, The Most Fundamental Right: Contrasting Perspectives on the Voting Rights Act, (Indiana University Press, 2012) 4.

21 John Patrick, Election Attitude: How Internet Voting Leads to a Stronger Democracy (Attitude LLC, 2016) 1.

22 Epiphany Azinge, Right to Vote in Nigeria: A Critical commentary on the Open Ballot System (1994) 38(2) Journal of African Law 173. 
until 1979 when women in the northern part of Nigeria were allowed to vote. ${ }^{23}$

Election rigging undermines the cardinal principle of democracy which upholds the welfare of the people as the object of government. ${ }^{24}$ Fear of election fraud drives honest citizens out of the democratic process. ${ }^{25}$ From historical experience, there are a huge number of challenges in manual electoral processes. These include poorly prepared or fraudulent voters' registers, inadequacy of electoral materials, (particularly the ballot papers) leading to the disenfranchisement of voters, snatching of ballot boxes from INEC officials, difficulty in transportation of electoral materials (especially ballot papers) after voting has been concluded. Other issues include electoral malpractices and violence. For many politicians and political contestants, winning an election is a matter of life and death. ${ }^{26}$ Election rigging and fraud are part of their overall campaign strategy: this is done in order to either gain an unfair advantage over their opponents or disrupt the process outright when it is clear that they have lost. ${ }^{27}$

The post-independence elections in Nigeria were the beginning of rigging of manual elections in its history. ${ }^{28}$ The tone of the 1964 elections was dictated by a set of events that took place in the period that followed independence in 1960. These were the imprisonment of Chief Obafemi Awolowo and senior members of his party, the creation of the Mid-Western Region out of the Western Region, the disputed census figures of 1962 and 1963, boycott of the election in the Eastern and Mid-Western Regions as well as in Lagos on allegations of rigging

23 ibid.

24 Lorraine Minite, The Myth of Voter Fraud (Cornell University Press, 2010) 2. See also Eje Odike, Hemen Faga Iruka Nwakpu, "Incorporation of Fundamental Objectives and Directive Principles of State Policy in the Constitutions of Emerging Democracies: A Beneficial Wrongdoing or a Democratic Demagoguery?" (2016) 7(4) Beijing Law Review 267-277.

25 Stephen Anoselabehere, Nathaniel Perislly, "Voter Fraud in the Eye of the Beholder: The Role of Public Opinion in the Challenge to Voter Identification Requirements" (2008) 21(7) Harvard Law Review 1738.

26 See Salahu Mohammed, "An Appraisal of Corruption in the Nigeria Electoral System" (2015) 11(25) European Scientific Journal 254.

27 Ibid.

28 The pre-independence elections in Nigeria recorded little or no fraud because of the following reasons, the colonialist were still at the helm of the affairs, not much was at stake as executive powers and as such the country's purse strings were still firmly in the grasp of the colonialists. 
and fraud and claims of opponent intimidation across the country. ${ }^{29}$ The 1964 federal elections saw politicians of the First Republic engaging in a battle of supremacy. The electoral process of the First Republic was therefore severely flawed. The political parties lacked restraint; there were massive rigging, intimidation, oppression, violence and wanton killings. Under these pressures, the electoral process broke down completely.

The 1965 Western regional legislative election proved to be the last straw that broke the back of the First Republic. After this election, the existing fragile peace could no longer be sustained, and the wanton rigging at the election ensured that the demise of the Republic was only a matter of time. The country's first military coup was a fallout of the problems and dissatisfaction generated by the conduct of the First Republic politicians. This subsequently led to the three-year civil war and the worst humanitarian disasters the country has ever known. ${ }^{30}$ The Republic came to an end on the heel of the flawed electoral system; the ghost of the crisis trailed the military which took over the reins of power. $^{31}$

During the 1979 elections, Nigeria adopted the Presidential System of government in the hope that the action will reinforce allegiance to the federation as a whole rather than to some particular section of it. An executive presidency was seen as a focus of national unity. Political parties were required to conform to certain norms and procedures, designed to ensure that they are federal in outlook. It was presumed that these factors would lead to an avoidance of the troubles of the First Republic which was brought on by regionalism. The electorate cast their vote on11 August 1979. ${ }^{32}$

The outcome of this election was controversial as there arose the need to interpret the meaning of "twelve-two-thirds" of nineteen states as the leading candidate did not secure 25 per cent of votes in twothirds of twelve states and two thirds of the local governments of the

29 Joseph Babatunde Osabiya, "Nigeria and Democratic Elections" (2014) 2 (3) Journal of Good Governance and Sustainable Development in Africa 54.

30 Nkasi Wodu, "How Nigerian Elections Democratise Violence" (2018) <https:/ /thenerveafrica.com/16445/how-nigerian-elections-democratize-violence/> accessed 3rd May 2018.

31 Ibid.

32 Salahu Mohammed Lawal, "An Appraisal of Corruption in the Nigeria Electoral System”(2015 ) 11( 25 ) European Scientific Journal, 261. 
thirteenth state; hence the government started on the back of a legitimacy crisis. ${ }^{33}$

The 1983 election was among the most chaotic ever held in the country. ${ }^{34}$ The overall perception of the 1983 election by the populace was that it was massively rigged. There were accusations and counteraccusations from the political parties of intimidation, manipulation of ballot papers, thuggery and fraud. Against the backdrop of the disputed electoral outcome, President Shagari's second term began on a most inauspicious note.

The Third Republic was however aborted by a coup d'état. The country was taken through its longest transition to civil rule as it witnessed more than a decade of military misrule. The transition to democracy timeframe was tinkered with by the military government. The elections of 1992 to 1993 were frequently delayed, cancelled, postponed and adjusted to produce a result predetermined by the Military.

Following the decision to return to democratic rule, the election of 1999 was welcomed with the greatest of enthusiasm. Three parties were registered for the process. These were the Peoples Democratic Party (PDP), All People's Party (APP), and the Alliance for Democracy (AD). The elections witnessed massive rigging and fraud. PDP was the clear winner as it won the presidency, majority seats in the legislature and 21 gubernatorial seats. APP had seven states governors while AD had six states.

The shortcomings of the 1999 elections were discountenanced because it was the first election after more a decade of military rule. The electoral outcome was generally favourable; though it was clear that the "parties lacked internal democracy and discipline". The 2003 election was described as "a coup d'état against the people. ${ }^{35}$ The PDP made what was considered fraudulent in-roads to opposition's enclaves. PDP won more states to take its total to twenty-seven states, majority holding in the legislature and the presidency.

The 2007 elections will go into history as one of the most criticized elections ever held in Nigeria. ${ }^{36}$ This is because of the obvious flaws

33 Molu Adediran, "Awolowo v Shagari-A Case of Compromise between Law and Political Expediency “ (1982) 24 Journal of Indian Law 48.

34 Ibid.

35 Footnote 31 above.

36 Jibrin Ibrahim, "Nigeria"s 2007 Elections Fitful Path to Democratic Citizenship" (2007) < https://www.usip.org/publications/2007/01/nigerias-2007elections-fitful-path-democratic-citizenship>accesed 9 May 2018. 
and fraud that characterized the elections. The violence that occasioned left not many in doubt about the illegality of the election. ${ }^{37}$ The nonpartisanship of INEC, which is supposed to be an independent and credible body, was doubted more than ever. Every aspect of the election was far from fair, and there were problems in the internal dynamics of some of the parties. The PDP alongside its lack of internal discipline engaged in several litigations and legal harassments of opposition thereby further putting a clause to the credibility of the elections. The fraudulent nature of the election was put in proper perspective with the chain of annulments and reruns pronounced by the election tribunals. This election also was also one of the few elections to be postponed due to poor logistic planning.

The conduct of the 2011 election came within improved legal parameters and ensured that INEC's independence was guaranteed. Indeed, there was a reduction in the number of litigations in the tribunals compared to the 2007 elections. The sore point of the election was the violence that erupted at the close of the process in which 1000 lives were lost. ${ }^{38}$ The violence seriously discredited the electoral process. The Corps members who were employed as the Ad-Hoc staff were severely disadvantaged as the majority of them especially in the North lost their lives in the violence that ensued as a result of the election. The 2015 election was equally marred by claims of election violence.

These problems with successive elections in Nigeria highlight Nigeria's incomplete search for a credible electoral system. The various challenges associated with manual voting systems must be thoroughly understood and addressed to carry out effective and meaning reform processes for Nigeria's electoral systems. These challenges are discussed in the next section.

\section{CHALLENGES OF MANUAL VOTING SYSTEM IN NIGERIA}

Traditional paper ballot system of elections in Nigeria have for many years struggled withfour complex challenges. They are:

37 Ibid.

38 Sunday Onwe David Nwogbaga, Mark Ogbu, "Effects of Electoral Fraud and Violence on Nigeria Democracy: Lessons from 2011 Presidential Election" (2015) 20 Journal of Humanities and Social Science 1-10. 
A. Logistical and transportation challenges: Traditional paper ballot election involves the movement of people (electorate and electoral officials) and election materials to the polling units and collation centre for vote casting, tallying and results. ${ }^{39}$ This has proved to be a complex exercise in Nigeria, given the population and geographical size of the country. ${ }^{40}$ Transporting election results through traditional means of transportation expose the results to numerous risks such as an attack by political thugs, aggrieved party members; or manipulation by corrupt INEC officials. ${ }^{41}$ These constraining factors negatively affect the reliability of the traditional paper ballot system and put to question the need for its continual adoption. The factors also open up a window for e-voting option for the simple reason that in e-elections, results are compiled and communicated electronically. ${ }^{42}$ IT experts involved in electronic elections, sit in the comfort of their offices and upload results within fractions of seconds. The results are beamed in minutes to the country, resulting in certainty for the contestants and the electorate. Furthermore lives are saved as there is no risk of the electoral officers being ambushed as they transport the materials for a concluded election to their headquarters to their office to collate. The motive for ambushing electoral officials and killing them in a bid to snatch the concluded election materials en route the polling stations or vice versa is thus strongly reduced. ${ }^{43}$

B. Disenfranchisement of Diaspora voters: Issues bordering around franchise continue to heat up Nigeria's political discourse. ${ }^{44}$

39 Amadu Kurfi, Nigerian General Elections 1951-2003: My Roles And Reminiscences, (Spectrum Books, 2005) 35.

40 Adele Jinadu, "Matters Arising: African Elections and the Problem of Electoral Administration," (1999) 2 (1) African Journal of Political Science 1-11. See also Said Adejumobi, Elections In Africa: A Fading Shadow Of Democracy (2000) 21(1) International Political Science Review, 60.

41 An official who spoke on the condition of anonymity informed that that when transporting election materials, they make a detour and re-write results.

42 Michael Alvarez, Tad Hall, "Electronic Voting: The Perils and Promises of Digital Democracy (Princeton University Press, 2008) 72.

431 Anthony Egobueze, Calistus Ojirika, Electoral Violence In Nigeria"s Fourth Republic: Implications For Political Stability (2017)(13) 2 Journal Of Scientific Research And Reports 6.

44 ibid. 
Disenfranchisement of a large number of Nigerian immigrants living in foreign countries poses serious concerns as they are desirous of exercising their fundamental human rights. ${ }^{45}$ In addition, electoral officials, security personnel on duty during election posted to places other than their polling units find it difficult to exercise their voting rights. The existing voting system does not support absentee voting; hence the agitation from various quarters within Nigeria and abroad to explore a viable voting system that allows voting right for those Nigerian citizens in the diaspora and the category mentioned above of citizens. ${ }^{46}$ Furthermore, this agitation is well-founded in the sense that if the Nigerian military personnel on overseas mission are declared fit enough to defend their country, which some of them do by paying the supreme price of laying down their lives, the least act of gratitude that the Nigerian government can accord to them is the right to exercise their franchise by e-voting. ${ }^{47}$ This is one of the strongest arguments in favour of e-voting. Equally, senior citizens who have diligently contributed to the growth and development of the Nigerian economy by working long and hard hours during their productive years, diligently paying their taxes should

45 Jean-Pierre Bongila, Grounding Leadership Ethics in Africa Diaspora and Election Rights (Lexington Books, 2013 ) 110.

46 Ibid.

47 The question whether members of the military should be allowed to vote at all remains a contentious one in several countries. While countries such as the United Kingdom, United States, Australia, Canada, South Africa, Germany, France amongst others, guarantee the rights of military officers to vote in elections, other countries such as Angola, Argentina, Brazil, Tunisia, Turkey and so on, do not confer voting rights on the military. In Nigeria, even though the Nigerian Constitution guarantees every eligible citizen's right to vote and, hence there are no limitations regarding the voting rights of the military personnel or other public servants, military officers are often disenfranchised due to lack of specialized options to exercise this right. In Canada, for example, during federal elections and referendums, members of the Canadian Forces can vote by mail or at polling stations set up in their units, using a special ballot, while some provinces such as Ontario and Nova Scotia provide for internet voting during provincial elections. See Special Voting Rules, Part 11, Division 2 of the Electoral Act. See Michael Meadowcroft, "Why the Military and the Police should Register and Vote" (2004) http://aceproject.org/ero-en/topics/ electoral-participation/why-the-military-and-the-police-should-register-andvote.pdf/view. 
not be denied voting rights for reason of infirmity. Where these classes of citizens cannot travel to the polling booth, they should have an alternative means of voting that does not entail leaving the comfort of their homes. E-voting enables this class of citizens to exercise their voting rights too.

C. Inadequate transparent mechanism: Another key problem of the existing voting system in Nigeria is the lack of transparency in the counting and collating processes. ${ }^{48}$ Electoral officials manually collate, count and announce election results. Hence, the method is prone to the danger of human error and deliberate manipulation. The susceptibility to rigging of the manual method of voting allows electoral officials with corrupt motives and their accomplices to easily rig the election at every stage of the process unnoticed. Furthermore, the manual system allows for multiple voting, voting by non-eligible persons; intimidation of voters, alteration of counted ballots before declaration, and manipulation of result during the long period between the closure of polls and declaration of results. ${ }^{49}$ E-election promotes transparency for it enables the authorities to count the votes from the moment that election starts, counting based on receipts with barcodes which is a feature of e-election increases the transparency mark for elections. ${ }^{50}$ At a time when elections - even in advanced democracies are tainted with allegations of fraud or outside influence, use of technology to eliminate rigging is imperative. All data of the election process in e-voting can be recorded on software while maintaining the anonymity of voters, with results available. For example, Estonia practices e-election. The electronic voting machine generates two sets of information at the end of every election when prompted to give access to scrutiny for any interested party. ${ }^{51}$ All significant documents

48 Nic Cheesman, Brian Klass, How to Rig an Election (Yale University Press, 2018) 157.

49 Bush v Gore 531 U.S. 98[2000].SC

50 Roghayeh Alamuti, Hassan Barjini, Manoj Khandelwal, Mohammad Jafarabad, "A Method to Improve Transparency of Electronic Election Process without Identification" (2015) 73 Procedia Computer Science 404.

51 Sutton Meagher, "When Personal Computers Are Transformed into Ballot Boxes: How Internet Elections in Estonia Comply with the United Nations International 
used in the e-voting system are also made public. To enhance the observers' knowledge of the system, the political parties are invited to take part in a training course before each election in which e-voting is used. Besides political parties, auditors and other persons interested in the e-voting system take part in the training. Also, observers are invited to follow the testing of the whole process and take part in other preparatory procedures. Procedures are fully documented, with those that are critical being logged, audited, observed, and videotaped as they are conducted. This inbuilt procedure fosters transparency in the election process as opposed to what is obtainable in manual elections.

D. Security challenges: Security is a key aspect in the exercise of voter franchise in Nigeria. Where lives and properties are at risk in general elections, there will be low voter turnout and apathy. Personal security of election personnel, contestants, media practitioners, observers and voters is paramount to the integrity of elections. Elections in Nigeria have been marred by widespread violence ever since its independence. ${ }^{52}$ This is particularly very telling in Nigeria as idle youths are used, who tout firearms superior to the ones wielded by police officers.

Political thugs follow a pattern of thuggery and violence namely, snatching of ballot boxes, harassing of election officials, injuring them and sometimes even murdering them for political gains. ${ }^{53}$

More than a thousand people were killed in the 2011 presidential elections. Youth corps members serving as ad hoc election staff were particularly affected; while a large number of ballot papers mysteriously disappeared from the police custody. ${ }^{54}$ Violence broke out almost simultaneously in Kano, Kaduna, Adamawa, Katsina, Plateau, Yobe,

Covenant on Civil and Political Rights" (2009) (23)2 American University International Law Review 349-38.

52 Chinyeaka Justine Igbokwe-Ibeto, Kehinde Osakede Ohiole, Barisua Barry Nkoma Ruth Fanny Kinge Election and Democratic Consolidation In Nigeria: An Analysis Of The 2015 General Elections 2016(5)10 Arabian Journal of Business and Management Review 1-14.

53 Shola Omotola , Aremu Fatai, "Violence As Threats to Democracy in Nigeria under the Fourth Republic 1999-2005" (2007) 6(89) Journal of African Asian Studies 53-79.

54 Bamgbose Adele, "Electoral Violence and Nigeria's 2011 General Elections" (2012) 4(1) International Review of Social Sciences and Humanities 210. 
Bauchi, Borno, Katsina and Sokoto States, leading to the imposition of state-wide 24hours curfew in some of the states. ${ }^{55}$ If e-voting were to be introduced in Nigeria, the security challenges faced by citizens in casting their votes would be greatly reduced if not eradicated. Citizen Joe may sit in the comfort of his home and use his mobile phone or personal computer connected to the internet to vote for the candidate of his choice.

Election officials will also upload results in real time before any opportunity is given for violence to erupt. Reduction in the number of people in polling booths where the majority, especially youths, have voted in the safety and comfort of their homes will reduce the motive for violence. Furthermore, electronic voting machine will be challenging for political thugs to operate successfully as technology and illiteracy are strange bedfellows. ${ }^{56}$ These thugs are normally illiterate. ${ }^{57}$ Where electronic processes are used to facilitate elections, the fidelity of the technology, its robustness against failure and deliberate distortions may also constitute part of election security. ${ }^{58}$

\section{E-VOTING: THE PANACEA TO ELECTORAL FRAUD IN NIGERIA?}

Adopting robust IT policies and programmes has been termed the most effective solution to the problems of weak democratic practice in Nigeria. ${ }^{59}$ Electronic voting can reduce election costs and increase civic participation by making the voting process more convenient. Critics maintain that without a paper trail, recounts are more difficult and may open the door for electronic ballot manipulation and that poorly-

55 Lancelot Anyanya, "Assessment of 2011 Elections in View of Recommendations from the 2010 Workshop" in Lai Olurode (eds), Election Security in Nigeria (Friedrich-Ebert-Stiftung Publishing 2013) 24.

56 They need to override the security and password codes as well as understand the software.

57 Peter Adebayo, Shola Omotola, "Public Perceptions of the 2007 Nigerian General Elections"(2007) 6(2) Journal of African Elections 201-219.

58 Mike Igini, "Election Security in Theory and Practice: Perspective of a Resident Electoral Commissioner" in Lai Olurode (eds) Election Security in Nigeria (Friedrich-Ebert-Stiftung2013) 43.

59 Godwin Onu, Amobi Chiamogu, "E-Governance and Public Administration in Nigeria: A Discourse.” (2012) 2 (9) International Journal of Management 1-8. 
written programming code, could affect election results. Polling place e-voting and remote i-voting systems of election have been used in different democratic societies. The United States, Australia, Estonia, Japan, Brazil and India are at various stages of e-voting adoption. ${ }^{60}$ In Africa, Namibia was the first country to transit to e-voting in its 2014 general elections. ${ }^{61}$

The advantage of e-voting over the conventional voting system is obvious. Convenience is an attribute of e-voting that enhances participation and remedies apathy associated with traditional voting methods. E-voting makes it easier for people to make their views known and cast their votes, an important requisite for a constructive democratic process. Furthermore, poorly designed paper ballots, which might have been filled in or counted incorrectly becomes a thing of the past if e-elections are adopted.

Abu-Shanab, Knight and Refai maintain that using e-voting improves the convenience, efficiency and effectiveness of the election process; reduces the cost of organizing the election, increases participation and improves the integrity of election process in general. ${ }^{62}$ Issues associated with inaccuracy, insecurity, fraud and forgery inherent in the conventional manual method of voting is non-existent in electronic voting; thus making it an appealing option. According to Kozakova, modern democracy would maximally benefit from effective implementation of electronic voting technology. ${ }^{63}$ Voting is not a costfree activity as cost of transportation, searching for polling booth and travelling on election day are tangible costs that entail spending time, money and effort. ${ }^{64}$ Assessing the tangible cost of voting vis-a-vis immediate benefits of same often guides the decision of the voter to either vote or not. The easier voting becomes for citizens, especially

60 Sanjay Kumar, Ektar Walia, "Analysis of Electronic Voting System in Various Countries" (2011) 3(5) International Journal of Computer Science and Engineering 1825-1828.

61 Oladotun Okediran, Rafiu Ganiyu , "A Framework for Electronic Voting in Nigeria"(2015) 129(3) International Journal of Computer Applications 12.

62 Emab Abu-Shanab, M. Knight, H. Refai, "E-Voting Systems: A Tool for EDemocracy" (2010) 2(3) Journal of Management Research and Practice 264274.

63 P. Kozakova, "Can "E-Voting" Increase Turnout and Restore Faith in Politics?" (2011)<http://www.eotwonline.net/2011/09/01/can-e-voting-increaseturnout-and-restore-faith-in-politics/ > accessed 9 May 2018.

64 Ibid. 
among the younger age, the more likely they are to participate in elections. Hence, a voting system that requires less effort, such as punching a button or clicking a computer mouse is likely to gain more acceptance. Such voting system increases voters' convenience and confidence in electoral procedure and is capable of improving the decline of voter turnout and perceived political apathy in Nigeria. ${ }^{65}$ Indigent citizens would similarly be induced to vote if they could avoid the cost of transporting themselves to the polling booths and voting in the comfort of their homes; thus saving the finances that may have been used for transportation.

Every citizen has the right to say how his country is to be governed, this fosters a sense of belonging to the citizen. To take this away is analogous to stripping him of one of his most basic freedom and fundamental human right. This is a great disservice to that citizen. Governments are more likely to command legitimacy, respect and obedience where the citizens elected them. Where the right to vote is proscribed, descent into despotism and chaos may arise. To run an effective democracy is an incentive to protect and guarantee the fundamental human rights of citizens to vote as enshrined in democratic constitutions. The hallmark of a good voter engagement is evidence of active participation and involvement in decision making by the citizenry. Besides eradication of rigging, fraud, manpower conservation, convenience, protecting the constitutional right of the identified group of citizens is one of the reasons for adopting this novel method of voting.

Furthermore, the Federal Republic of Nigeria is bound by the rule of law. Therefore, to uphold e-voting, conformity with the legal system is paramount, especially the Constitution. Inculcating e-voting supports the theory of inclusiveness, voter franchise and voter inclusiveness encapsulated in the Universal Declaration of Human Rights, International Covenant on Civil and Political Right.

E-voting equally promotes citizenship and affinity, which is a constitutionally guaranteed right. ${ }^{66}$ Citizenship in a democracy is a

65 Mike Burmester, Emmanouil Magkos., "Towards Secure and Practical E-Elections in the New Era" in Dmitri Gritzalis (eds) Secure Electronic Voting. Advances in Information Security, Vol 7. (Springer 2003) 63.

66 Chapter three of the 1999 Constitution of the Federal Republic of Nigeria guarantees this right. Article15 of the Universal Declaration of Human Rights states that "everyone has the right to a nationality" and that "no one shall be arbitrarily deprived of his nationality nor denied the right to change his nationality". 
source of all authority, right and power. A citizen is a full and equal member of a polity in any democratic nation-state; ${ }^{67}$ thus to cast a vote at the election is one of the highest honours a citizen of a country can have. Consequently, in Trop v. Dulles, the right to citizenship was described as the "right to have rights." 68 Individuals who lack a nationality or an effective citizenship are therefore among the world's most vulnerable to human rights violations. Citizenship is, indeed, the social and legal link between individuals and their democratic political community. The status of citizenship involves important responsibilities and duties that have to be fulfilled, and where these are not fulfilled, democracy becomes a mirage.

Most ICT development projects and initiatives in developing countries are greeted with implementation, sustenance and maintenance challenge owing to lack of critical evaluation of the social environment in which these projects are transplanted. Therefore, before embracing western approaches, culture and technology, it is important for developing countries to assess the readiness to sustain these ideas, the financial cost, the economic capital required, and the intellectual capacity of citizens to absorb and appreciate these imported ideas. ${ }^{69}$ In most cases, due diligence studies are rarely commissioned to assess the practicability of such foreign ideas. ${ }^{70}$ The end result sometimes amounts to the failure of these ideas in developing countries as well as the loss of the finance earmarked for these projects or ideas. ${ }^{71}$ For instance, despite the enormous amount of funds channelled to the 2015 general elections to acquire the card reader, 41 per cent of the

67 Chantal Mouffe, "Citizenship" (1995) 1 Encyclopedia of Democracy 217-221.

68356 U.S. 86, 101-02 [1958)].

69 On the importance of technology absorption in Africa, see Damilola Olawuyi, "From Technology Transfer to Technology Absorption: Addressing Climate Technology Gaps in Africa" (2018) 36:1 Journal of Energy \& Natural Resources Law 61-84.

70 Olawuyi, ibid.

71 The 2015 election cost Nigeria US\$625 million. The country's huge cost of elections has surpassed that of the world's largest democracy, India, with a population six times bigger than Nigeria's. Nigeria, with 67 million registered voters, spent US\$625 million during the 2015 elections, translating into US\$9.33 per voter, according to data prepared by the National Institute for Legislative Studies (NILS) in 2015 see, "The Cost of Running Elections- A Cross Country Comparison" (2015) < http://nils.gov.ng/docs/cost_of_elections.pdf > accessed 7th May 2018. 
card readers failed; INEC had to resort to manual verification and accreditation. ${ }^{72}$ This has stressed the need to address the challenges that arise from adoption e-elections. The article will now examine legal challenges that must be understood and addressed before e-voting systems can be sustainably adopted in Nigeria.

\subsection{Legal and Institutional Challenges to Adopting e-Elections in Nigeria}

The adoption of e-elections in Nigeria is bound to raise a lot of legal questions and challenges. Issues will crop on the illegality or otherwise of the said elections. The time to prepare for this oncoming challenge is now.

Most constitutions of the world uphold the right to vote as a fundamental human right. This right is embedded deeply into any democratic culture. Article 25 of the International Covenant on Civil and Political Rights (ICCPR) states, "every citizen shall have the right and the opportunity to vote and to be elected at genuine periodic elections, which shall be by universal and equal suffrage and shall be held by secret ballot, guaranteeing the free expression of the will of the electors". Article 21 of the Universal Declaration of Human Rights 1948 (UDHR) stipulates, "Everyone has the right to take part in the government of his country, directly or through freely chosen representatives. The will of the people shall be the basis of the authority of government; this shall be expressed in periodic and genuine elections, which shall be by universal and equal suffrage and shall be held by secret vote or by equivalent free voting procedures."

In Nigeria the constitutional right to vote for any Nigerian citizen who has attained the age of eighteen years (though not contained in the section for fundamental human rights) is provided for in sections and subsections of 77 (2); 117 (2), 132 (5) and 178 (5) of the 1999 Constitution. From the above legislation and the international legal instruments, it can be gleaned that enfranchisement is of great importance in any legal discourse. That is why the right to vote is firmly entrenched in these legislations. An ancillary to the right to vote is the right of access to vote; the right of access necessitates discussions

72 Chikodiri Nwangwu, "Biometric Voting Technology and the 2015 General Elections in Nigeria" (The 2015 General Elections in Nigeria: The Real Issues Conference, (Abuja, 27 July 2015) 16. 
concerning the inability to vote of some citizens who are willing to but not afforded the opportunity of voting either by reason of being overseas (serving the fatherland in the example of military personnel), incapacitated, old or infirm. These groups of people, through no fault of theirs, are disenfranchised from performing the most important of their civic duties were manual voting the only means of exercising the franchise. The issues that e-voting would surmount in Nigeria to be deemed a legitimate means of elections include legality of the use of SCR, harmonization questions, logistical and institutional questions, technological and infrastructural concerns, and protection of citizens' data.

\subsubsection{Legality of the Use of SCR}

The first of the legal challenges faced in Nigeria's slow and gradual march to embracing e- election was the legality of the use of the SCR in the 2015 general elections. ${ }^{73}$ This was one crucial aspect of the election that critics of the card reader contested. In Shinkafi $v$ Yari $^{74}$ Okoro JSC observed, “... the function of the card reader machine is to authenticate the owner of a voter's card and prevent multiple voting by a voter." Section 52(2) of the 2015 Electoral Amendment Act says, "voting at an election shall be in accordance with the procedure determined by the Independent National Electoral Commission." ${ }^{75}$ The above section highlights a substantial gap in the country's electoral laws. Concrete predictable section, which allows e-voting should be substituted for s 52(2). The process of voting or franchise is so sacrosanct that the legislations governing it should not be vague or ambiguous. The substitution may read "e-voting is the procedure (or the/a recognized procedure) for filling elective posts in Nigeria." In addition to a definitive nod and pronounce of e-voting as a system of election, the amended electoral law should also stipulate specific prescription, guidelines, and the method of conducting such elections. When this is done, this will confer on electronic voting the legitimacy it requires and will not subject it to protracted litigious battle in courts of the land by losers of electoral contests.

73 See above Okereke v Umahi.

74 (Unreported suit no 907/2015 of 8 January 2016).

75 INEC in exercise of the powers conferred on it by this section replaced manual accreditation with electronic accreditation in the 2015 presidential elections. 
Similarly, the Nigerian Constitution does not specifically mention Internet or electronic voting either, rather s.77 of the 1999 Constitution of the Federal Republic of Nigeria states, "every citizen of Nigeria, who has attained the age of eighteen years residing in Nigeria at the time of the registration of voters for purposes of election to a legislative house, shall be entitled to be registered as a voter for that election." The issue of legal gap in the jurisprudence of elections in Nigeria does a great disservice to the age-long function of the law, i.e. certainty. ${ }^{76}$ This lacuna in the Nigerian legislation concerning e-voting ought to be filled to run a credible election. Judges should not be left to create laws in the important matter of elections. Courts have their own function; it is, therefore, not the constitutional duty of the judiciary to make laws but to interpret laws and review the constitutionality of laws. Personal beliefs, sentiment and political leaning of judges may colour their judgments if the lacunas created by the non-enactment of the e-voting legislation is left to be filled by judge-made pronouncements. This would be a great disservice to the nation if it occurs ${ }^{77}$ as judge-made laws are not subject to scrutiny, public debates, rigorous stages, that regular legislations pass through before they become laws. The legal framework for e-voting should equally cover the minimum procedural, regulatory and technical standard to be met.

\subsubsection{Harmonization Questions}

Another key step to be taken in harmonizing Nigerian legislation to reflect electronic voting is to adopt a comprehensive review of other relevant legislations to ensure that all aspects of e-voting are legally covered and appropriately regulated. Apart from the Constitution and the Nigerian Electoral Act, other legislations which impinge on elections, such as Criminal law, Evidence law, Contract laws, Administrative laws, Cybercrime Prohibition Prevention Act, and so on should be amended. New provisions should be included to deal with any legitimate complaints in e-elections. For example, s. 84 (1)-(5) (C) of the Evidence Act 2010 contains provisions on electronic or computer-generated evidence. Section 84(1) states: "In any proceedings, a statement contained in a document produced by a computer shall be admissible

76 Einer Elhauge, Statutory Default Rules: How to Interpret Unclear Legislation" (Harvard University Press, 2008) 23.

77 See Abiola v FRN [1995] 7 NWLR [Pt.405] 1. 
as evidence". It seems from the wordings of this section that e-voting has passed the first hurdle in instances of admissibility of data stored on electronic voting machines or the Internet. Section 258 of the same Act also defines a computer to mean "any device for storing and processing information". Harmonization will aid avoidance of overlap and inconsistencies in legislations. Codification of the nation's electoral laws is advocated as it makes electoral law simple and accessible to everybody. Citizens may, therefore, know their electoral rights and duties and thus resist browbeating by corrupt politicians.

Harmonizing and codifying electoral laws in a coherent form, reduce the chances of conflict arising from the different provisions of the electoral law. This affords stability and development of the country.

\subsubsection{Logistical and Institutional Questions}

A national election is one of the country's biggest logistic ventures. Personnel and materials must get to the polling units at the right time and in good shape for elections to take place as scheduled. INEC staff should be proficient, especially in the use of modern technology deployed. They also should be trained and certified on all electoral devices. All logistic support should be provided in conducting e-voting. Teething problems should also be envisaged and plugged as any flop in logistics will be termed an attempt to disenfranchise the citizens; hence, the need to plan adequately with logistics operators and security agencies. The shift from manual to electronic voting will also influence the procedure for observation missions. In future, electoral observation will include an examination of the EVMs to rule out irregularity.

This changes the expertise needed to observe elections. The proposed amendments of legislations should incorporate procedures for accommodating international observers and training them. This will facilitate independent monitoring that can be examined to access the quality of the election. An open and inclusive process for deliberating on any legal amendments concerning these issues is vital to winning public confidence and reaching an agreement with potential electoral contestants on the new rules of the electoral competition. In administrative experiences, the best services are rendered to chief executive officers, and this trickles down according to hierarchy. If the card reader designated to accredit the president of the Federal Republic of Nigeria could fail to capture his data, the ordinary citizens in hinterland would fare much worse. The SCR equally malfunctioned 
severely in Ebonyi State and across the country in the same election. ${ }^{78}$ Officials and campaign workers need to adapt to changing circumstances, know the limits of their methods, and combine new SCR technologies and knowledge to achieve an overall balance. ${ }^{79}$ Training for voting operations staff is a valuable investment in the integrity of the election process as these officials make or break elections. It is a necessary and integral part of each election and ensures that all staff have the competence to apply election procedures accurately, impartially, and consistently in every election.

\subsubsection{Technology and Infrastructure Concerns}

E-voting faces a wide variety of potential attacks more than those considered in traditional elections. The UK first trialled e-voting in $2000 .{ }^{80}$ Emanating from such experiences of the past are the security of the systems and voter confidence, which need to be tackled in e-elections. Among the practical challenges facing e-voting is the inadequacy of election software security. Election software is more than an ordinary computer application that has to be kept safe. Given that political power, control of the purse strings of a nation are the basic issues in an electoral contest, the stakes are high in elections for public office. Thus the incentive to cheat is enormous, and the consequences of a fraudulent outcome could threaten social order and national sovereignty. ${ }^{81}$ Failed elections have serious social, economic, political and sometimes even human costs. The technology challenges faced in e-elections include insider attacks from system administrators, and cybercriminals working for dishonest sophisticated nation-states

78 Emmanuel, Aziken, "Card Readers, Lessons from Other States" (2015) < https:/ /www.vanguardngr.com/2015/03/card-readers-lessons-from-other-lands/> accessed 15 May 2018.

79 Chapman Rackway, "Trickle-Down Technology? The Use of Computing and Network Technology in State Legislative Campaigns" in Costa Panagupoulos (eds), Politicking Online: The Transformation Of Election Campaign Communications (Rutgers University Press 2009) 77.

80 Lawrence Pratchett Melvin Wingfield "Electronic Voting in the United Kingdom, Lessons and Limitations from the UK Experience" in Norbert Kesting Harald Baldersheim (eds), Electronic Voting And Democracy, A Comparative Analysis (Palgrave Macmillan 2004) 172.

81 Alex Halderman "Practical Attacks on Real World E-Voting" (2016) < https:// jhalderm.com/pub/papers/ch7-evoting-attacks-2016.pdf $>$ accessed on 9 May 2018. 
applying offensive cyber warfare capabilities. Consequently, they expose what might otherwise be a regional election to attackers from around the globe. These attackers' goals could either be to tamper with the election outcome to favour particular candidates; discovering how people voted, e.g. to retaliate against those who voted against the attacker's preferred candidates or disrupt or discredit the election process, e.g., through denial of service attacks. ${ }^{82}$

The adoption of e-voting may expose INEC to cyber-attacks. The threat of cyber-attacks in e-elections is very real - as real as desperate politicians snatching ballot boxes and rigging the elections! Various local incidents support the view. In Nigeria, for example, during the accreditation exercise for presidential and national assembly elections in 2015, INEC website was hacked by a group, which called itself Nigerian cyber army. The group said they hacked and took control of the website to protect results from being manipulated by anyone through any means. This shows that our cyberspace is not safe; websites of government establishments, as well as private firms, could as well be compromised by hacking. This group could hijack the INEC website and manipulate the information fed to INEC's website by the SCR. They may favour a selected candidate which amounts to election rigging and stolen mandate which is the bane of manual elections in Nigeria. ${ }^{83}$ Incidentally, there has been no arrest or prosecution of these cybercriminals.

Also, in Nigeria, there is a cybercrime specific legislation, the Cybercrime Prohibition Prevention Act, 2015. This law should be invoked to bring the hackers to book. We equally boast of a large police force whose duty is to eradicate crime. Statistics show very little conviction for cybercrime, if any, three years after passing the legislation. There is an urgent need to regulate our cyberspace if the government is committed to introducing e-voting system of election. Nigeria has an inglorious reputation for cybercrime. It is ranked third in the world behind UK and US in Internet crimes. ${ }^{84}$ With the proliferation of cybercriminals in Nigeria, they may become tools in the hands of

82 Ulle Madise, Priit Vinkel, Constitutionality of Remote Internet Voting: The Estonian Perspective. (2011) 28 Juridica International Law Review 14.

83 Mansur Ibrahim, "Updated; Hacked INEC Website Restored", <https:// www.thecable.ng/breaking-inec-website-hacked> accessed 17 May 2018.

84 Mohammed Chawki" Nigeria Tackles Advance Fee Fraud" (2009) Journal of Information, Law \& Technology 3. 
unscrupulous politicians to rig elections. If this is unchecked, e-voting in Nigeria would be plagued with the same challenges of rigging, fraud, and stolen mandate that bedevil manual voting. Given the money and political power in play during a high-stakes election for public office, the incentive to cheat is enormous, and the consequences of a fraudulent outcome could threaten social order and national sovereignty. ${ }^{85}$

Over the past decade, attackers have become increasingly sophisticated, and critical systems such as election software now face potential attacks from advanced cybercriminals and even statesponsored attackers. ${ }^{86}$ While Internet-based financial applications, such as online banking, share some of the threats faced by e-voting, there is a fundamental difference in the ability to deal with compromises after they have occurred.

In the case of online banking, transaction records, statements, and multiple logs allow customers to detect specific fraudulent transactions - and, in many cases, allow the bank to reverse them or write it off as part of the cost of doing business ${ }^{87}$ Fraudulent election results cannot be written off. ${ }^{88}$ In 2007, various local government councils in England, namely, Shrewsbury \& Atcham, Sheffield, Rushmore and Swindon adopted e-elections for voting. In the aftermath of the elections, the UK Electoral Body commissioned a report on the outcome of these eelections. ${ }^{89}$ It was found that a significant number of polling stations experienced technical problems at some time or another on polling day.

The level of security assurance of the elections was below that associated with other government IT projects, and best practice in

85 Tadayoshi. Kohno, Adam Stubblefield, Aviel Rubin, Dan Wallach, "Analysis of an Electronic Voting System" (2004) < http://citeseerx.ist.psu.edu/viewdoc/ summary?doi=10.1.1.130.1712 > accessed 2 May 2018.

86 The allegation that Russia tampered in 2016 United States Presidential Election has been confirmed by US intelligence officers. The then President Obama expelled Russian diplomats from American soil to register his displeasure.

87 “True Cost of Fraud Study" (2014. ) < http://www.lexisnexis.com/risk/ downloads/assets/ true-cost-fraud-2014.pdf.> accessed 8 May 2018.

88 Scott Wolchok Eric Wustrow Dawn Isabel Alex Halderman. "Attacking the Washington, DC Internet Voting System." in Angelos Keromytis (eds) Financial Cryptography and Data Security (Springer Publishing 2012)114.

89 Electoral Commission Report (2010) < https://www.electoralcommission. org.uk/_data/assets/electoral_commission_pdf_file/0008/13220/ Electronicvotingsummarypaper_27194-20114__E_-N_S ${ }_{--}{ }_{-}{ }_{--} . p d f>$ accessed 4 June 2018. 
security governance was not followed. Equally the use of electronic machines was the most widely deployed electronic voting platform in the U.S. in the November 2006 general election. Many design errors and vulnerabilities were discovered in the EVMS. ${ }^{90}$ Nigeria could learn a lesson from the two jurisdictions by fortifying EVMS from vulnerabilities instead of abandoning e-voting. One option would be by using a software architecture system, with several layers of encryption that are difficult to break in. As the years pass, sophisticated design of protection could be manufactured so that the software technology used by the British and American governments, which featured vulnerabilities, may become obsolete in the technology world now with the advent of block chain technology system. Nigeria should also invest in the best software technology available and not scrimp on costs as a free and fair election is an investment, not a cost. The return on the investment will be reaped where there is legitimacy of the government conferred on it by the citizens who felt that their votes counted and that their voices were heard.

Another promising way forward to stop cyber-attack in e-voting is maintaining closer collaboration between researchers and election officials - to develop verifiable e-voting systems that are suitable for real-world use. Care should be taken to be especially vigilant in the hiring of contractors that would supply e-voting equipment, extensive vetting of these companies and picking only the best, as opposed to lobbying, will ensure that the best and brightest are retained to ensure a free and fair election devoid of manipulations and fraud. Electronic voting systems are critical infrastructure that must be defended and protected from attacks, with the same importance and vigour, as the power grid or financial system of the country.

\subsubsection{Protection of Citizens' Data}

Privacy of voters may be severely compromised by IT equipment long after elections have been won and lost. In a bid to enthrone e-voting, it is imperative to protect the fundamental rights of people regarding the processing of their personal data. Breach of citizens' fundamental human right to privacy is not the goal of e-elections. In Nigeria, a harmonized data protection legislation defining data, creating

90 E-voting was discontinued as a means of conducting federal elections in the US and specifically discontinued for all elections in the UK. 
boundaries and clearly distinguishing the rights of data owners should be promulgated. In elections, sensitive personal data, including those relating to religious or other beliefs, sex, ethnicity, political views, are revealed. These sets of data are special. Thus more stringent conditions should be attached to their collection and processing. Parties and individual candidates actively seek voter registers for a number of reasons, such as campaigns. Election data would undoubtedly be very valuable for political consultants, election system vendors and marketing firms. ${ }^{91}$

Personal data, especially those relating to participation and electoral behaviour, such as information necessary for registration, authentication or verification of calculation, should not be considered a simple source of revenue for authorities. Selling of citizens data infringes Article 21 of the Universal Declaration on Human Rights and S. 37 of the Nigerian Constitution. The data controller, in this case, INEC, should take all necessary measures to prevent such use. Personal data related to, needed for or produced by election procedures must be used only for the defined purpose, i.e. for organizing and holding elections, and in a way compatible with this purpose. For the same reason, the use of cookies on polling sites should be strictly prohibited given that it may reveal personal information related to the e-voting procedure. Unauthorized access and secondary use of data may restrain voters from exercising their rights and consequently pose a threat to democracy.

\section{RECOMMENDATIONS}

This section discusses some of the urgent legal and institutional reforms that are required to advance a reliable, credible and sustainable e-voting system in Nigeria.

\subsection{Need for a Harmonized and Enabling Legislative Framework}

Nigeria's current electoral law does not envisage or recognize e-voting. Attempts to introduce e-voting have therefore been analogous and

91 Lillian Mitran, Sokratis Kastikas, Dmtri.Kritzalis, Gerald Quirchmayr, "Electronic Voting: Constitutional and Legal Requirements, and Their Technical Implications" in: Dimtri Gritzalis (eds) Secure Electronic Voting. Advances in Information Security (Springer Science+ Business Media 2003) 43. 
derivative. Analogous reference to e-voting is not in the best interest of Africa's largest democracy. There should be specific legislation to support e-voting in Nigeria. E-voting is not merely an extension of everyday transactions and Internet applications in commerce and government, but a way to exercise a political right, deeply embedded in democratic traditions and constitutions: its introduction and acceptability depends upon its ability to respect, safeguard and promote the principles of fair play, enfranchisement and pertaining to this, most decisive, component of democracy. ${ }^{92}$ First, the Constitution should be amended to accommodate e-election. This amendment of the Constitution will give e-elections the fundamental legitimacy it needs in the event of a challenge in courts of law. The Constitutional amendment ought to reflect the principles of equality, universal adult suffrage, and confidentiality of votes cast.

This amendment would equally provide an opportunity to move voting rights to the fundamental human rights part, i.e. (Chapter IV of the 1999 Constitution of the Federal Republic of Nigeria). The gains of moving to the right to vote to the fundamental human rights chapter are that it will give voting rights a first-class status as a first generation right; more so the protection given to fundamental human rights (FHR) in Nigeria will be accorded to the right to vote. An example of this protection is a waiver of locus standi for FHR litigations. Paragraph 3(e) of the Preamble to the Fundamental Rights Enforcement Procedure Rules (FREPR) 2009 provides that the Court shall encourage and welcome public-interest litigations and no human rights case may be dismissed or struck out for want of locus standi. Thus, human rights activists, advocates or groups as well as non-governmental organizations may institute human rights applications (in our instance voting) on behalf of any potential applicant.

To this end, an applicant in human rights litigation may include anyone acting in his own interest, anyone acting on behalf of another person, anyone acting as a member of or in the interest of a group or class, persons or anyone acting in the public interest and any association acting in the interest of its members or other individuals or groups. Furthermore, the Electoral Act should be amended to include policy, procedures and regulations for conducting e-elections in Nigeria. The policy issues, which the proposed legislation should aim to tackle, are

92 Ibid. 
voter fraud, irregularity or unreliability of voting machine, inconvenience, delays, wasting of man hours, and voter unfriendly software among other things. Other areas that need to be tackled by the new Electoral Act are transparency, security, certification requirements of the electoral machines, and audit requirements. Equally, procedures for challenging results generated by electronic voting or counting machines should be provided for in the Evidence Act. The criminal law of the Federal Republic of Nigeria needs to reflect electronic criminality, and electoral deceit (for instance, manipulation of software, phishing, and spamming, Trojan horses) as traditional crimes may not fit into the scope of electronic crimes. Identity theft of voters should also be tackled to avoid violation of the privacy of voters.

The Cyber Crime Security Act should incorporate the stringent penal deterrence for hackers and malware code writers; likewise, the privacy of voters should be protected. One other amendment to be made in The Evidence Act is the provision of stringent tests regarding the adoption of computer-generated evidence, especially pertaining to elections where political power and economic power are at stake. Incidences of doctored reports, altered documents, manipulated election results, manipulated software, and superimposed figures are plausible. Currently, Nigeria has no data protection law. E-voting has opened an opportunity also to enact a data protection legislation, including to protect the private information of citizens.

In addition, personal data needed for or produced by election procedures must be used only for the defined purpose, i.e. for organizing and holding elections, and in a way that is compatible with this purpose. Finally, the proposed legislation on e-voting should be technically neutral as Information and Communication Technology (ICT) is a fastgrowing area, and no one wants to be tied down by outdated ICT specifications. Furthermore, the current Electoral Act refers to physical ballot boxes and ballot box seals, and how ballots are counted and adjudicated. ${ }^{93}$ It would be anachronistic since electronic voting machines will replace ballot boxes, thus, other provisions of the Electoral Act which make reference to manual voting and its procedures should be expunged.

93 S 44 of the Electoral Act 2010 States that the electoral commission shall be in charge of the forms of ballot papers, the section equally states that ballot papers should be bound in booklets, nominated serially and printed in colour codes for each office being contested. 


\subsection{Addressing Technology Concerns in Electronic Voting}

The integrity of an electronic voting machine is essential for public acceptance of e-voting. Given Nigerian citizens' cyber habits, the integrity and veracity of electoral data may be at risk. Technology concerns should be given priority to protect the integrity of data and the veracity of the data. Voters, parties and candidates must be assured that there has been no malpractice. Trust in an online voting system means having confidence in the machinery and infrastructure. As a result, in the case of e-voting, much more trust in the technology is needed, as well as in the roles and characteristics of the persons involved (election officials, technology providers). Infrastructure and equipment should be open to inspection by authorized bodies and parties' representatives. There should be policy guiding the manufacture of the electronic voting machines/software, minimum specification tests should be put in place, and the machines should guarantee that one vote means a vote, avoiding multiplicity of votes for a single voter. There should be a contractual guarantee by manufacturers of electronic voting machines (EVM) guaranteeing, inter alia, that votes cannot be intercepted nor modified or be known before the official counting; vote secrecy is guaranteed and that it never will be possible to link voters to their votes; the number of cast votes will be equal to the final tally of the number of received; it will be possible to prove that a given citizen has voted; and the system will not accept votes outside the voting opening period. ${ }^{94}$

The Act should also make provisions for encryption technology using digital signature as a form of identification of legitimate voters. This digital signature should confirm voters' electoral ward, preregistration and identification.

\subsection{Costs, Capacity and Resources}

The 2015 election was Nigeria's costliest election. ${ }^{95}$ With the current financial status of the country, that election's cost was astronomical

94 Thomas M Bauschbaum, E-Voting: International Developments and Lessons Learnt, in Alexander. Prosser, Robert. Krimmer (eds.), Electronic Voting in Europe: Technology, Law, Politics and Society Perspectives on Human Rights. (Bregenz: GI Lecture Notes in Informatics, (2004) 31-41.

95 Emmanuel Aziken, Emman Ovuakpuorie, Johnbosco Agbakwuru, Omeiza Ajayi "2015 Election Cost N1 Trillion - INEC" Vanguard News Paper (Lagos, 1 February 2017) 6. 
and with the paucity of funds in the coffers, Nigeria cannot afford another trillion naira election. ${ }^{96}$ E-election is a panacea of the exorbitant election. In manual elections, ballot papers are printed for each election making them recurrent costs. Each election, whether presidential, local government, gubernatorial or senatorial, requires a fresh set of ballot papers printed. In the event of a rerun, more ballot papers are yet printed. With e-elections, however, there would be no need to print and transport millions of electoral ballots and purchase ballot boxes. EVMs are used and reused till their productive life is over. Depending on their lifespan, they may be used for ten or twenty years. In the May 2018 local government election, the Kaduna State Government saved N1.7 billion by adopting e-voting. ${ }^{97}$ This figure is the amount that could have been spent on the printing of ballot papers.

This printing of ballot papers comes at a huge cost to our environment. For every tree that gets cut down and for every one tonne of paper produced, the ozone layer is seriously depleted. Environmental pollution caused by travelling to polling booths in diesel or automobiles by citizens to vote will equally be reduced if citizens can vote at home via their phones. Capacity training in the use of EVMs is essential for INEC staff as well as conducting pilot trials for voters to familiarize themselves with EVMs. This importance of voter outreach cannot be overemphasized as the level of illiteracy is high in Nigeria. ${ }^{98}$ Continuous sensitization of citizens in places of worship, town halls, markets and public places will give them enough confidence to use the electoral machine. These activities should be thought of as a public investment that is necessary to ensure popular acceptance and trust in the e-voting system.

\subsection{Political Will and Commitment}

Problems in the legal framework, political and administrative problems in the pre-election period and the integrity of elections on election days produce a negative effect on election results. ${ }^{99}$ Political will exists

96 Nigeria Yet to Recover From Recession - Kale, Punch (Akure, 20 August 2018) 13.

97 "Kaduna LG Poll: Governor El-Rufai Speaks on Electronic Voting, APC Victory" Premium Times (Abuja, 15 May 2018) 27.

98 Azizat Adegbegba, "60 Million Nigerians Are Illiterate - Minister", Premium Times (Abuja November 23 2017) 32.

99 Jessica Fortin-Rittberger, Philipp Harfst, Sarh Dingler, "The Costs of Electoral Fraud: Establishing the Link between Electoral Integrity, Winning an Election, 
when a sufficient set of decision-makers with a common understanding of a particular problem on the formal agenda is committed to supporting a perceived, potentially effective policy solution. Real political will involves a commitment to real solutions to challenges. Government must be committed to the eradication of electoral fraud. The local government election held on 12 May 2018 in Kaduna State has been a testament to the fact that Nigeria stands to gain a lot if it adopts e-voting. The Kaduna council election was the freest and fairest election in the history of Nigeria and voters were not confused about the use of EVMS. This has revived the confidence of many Nigerians about the possibility of a fraud-free election. Where a component unit in Nigeria successfully conducted e-voting without any hitch, the Federal Government should learn from the example set by adopting the evoting model of the Kaduna State Government, which has translated into enacting new legislation to accommodate e-elections. In showing the political will to adopt e-election and ensure its success, a think tank committee should be set up consisting of experts in electoral law, computer science, and software programming to develop a blue print for adopting e-elections in Nigeria. Their findings and recommendations should be adhered to and not shelved. Furthermore, even with a broken electoral commission, credible elections can still happen if the state has enough access and capacity, which can be augmented by international support, to police electoral conduct effectively. ${ }^{100}$

\section{CONCLUSION}

Democracy relies on voters having well-founded trust in the processes used to collect and count their votes. No system is perfect, but some are clearly more vulnerable than others. E-voting is Nigeria best chance of securing a credible, fraud-free election system for Africa's largest democracy. Hackers will always attempt to hijack electoral results to favour a candidate, either for financial gain or for fun. Given Nigeria's reputation with cybercrime, its peculiar problem with idle youth, it is predictable that when Nigeria transits to e-voting, unscrupulous people

and Satisfaction with Democracy" (2017) 27(3) Journal of Election Public Opinion and Parties 350-368.

100 Nils B. Weidmann Michael Callen "Violence and Election Fraud: Evidence from Afghanistan" (2013) 43(1 ), British Journal of Political Science, 53-75. 
will still attempt to hijack the process. To safeguard against this, besides the constitutional and other ancillary legislative amendment advocated for above, INEC should provide convincing evidence that a high standard has been achieved, by being transparent about their security measures and engineering processes. They should invite hackers to highlight the vulnerabilities of EVMS if any.

Furthermore, full training for staff involved in election and certification of the equipment by manufacturers should be emphasized to avoid a repeat of the embarrassment of a failed card reader which transpired in the 2015 general election in Nigeria. These measures will serve as a check to ensure that the e-voting system is not deemed a failure when it is fully rolled out. Also, the international community, especially the United Nations, should create an optional protocol to the ICCPR to encapsulate procedural and technical standard for e-elections. Nations ought to know what the minimum standards are in developing legal systems for e-elections. This proposed reform of constitutional law, electoral law and ancillary legislation to legitimatize e-voting in Nigeria are complex undertakings, and so it is imperative to begin this process as early as possible. 